\title{
МЕЖДУНАРОДНАЯ ДЕЯТЕЛЬНОСТЬ
}

\section{МЕЖДУНАРОДНОЕ СОТРУДНИЧЕСТВО РОССИЙСКИХ УНИВЕРСИТЕТОВ В ИМПЕРАТИВАХ РЕГИОНАЛЬНОГО РАЗВИТИЯ}

\section{Коппективная монография}

\author{
Ilod pedaxuиeü \\ Iрошева A.P., Крамарова С.О., Пелихова Н.В.
}


Монография издана при поддержке гранта РФФИ (проект № 18-410-860008 p_a)

Авторский коллектив:

Антипина И.В. (3.2, 3.3); Арбатская Е.Н. (2.5); Безуевская В.А. (1.2); Варламов Г.В. (2.4); Грошев А.Р. (1.3); Крамаров С.О. (1.4, 1.8); Круалов В.И. (2.1); Кушников Е.И. (1.7); Лаврова Е.Ю. (3.4); Махотаева М.Ю. (2.4); Матрохин А.Ю. (1.6); Пелихов Н.В. (1.1); Родионова А.В. (1.4, 1.5, 1.8); Салюкова Н.Н. (3.5); Сагайдак Е.И. (2.2, 2.3); Северина Ю.В. (2.3); Стороженко М.В. (1.4, 1.8); Трофимова Е.А. (3.6); Тряпельников А.В. (3.7); Тюрина П.Д. (3.3); Харитонова Т.Г. (3.1); Храмов В.В. (1.8)

Международное сотрудничество российских университетов в M43 императивах регионального развития : коллективная монография / Под ред. А.Р. Грошева, С.О. Крамарова, Н.В. Пелихова. - М. : РИОР, 2018. - 127 с. - (Международная деятельность). - DOI: https://doi. org/10.29039/2006-7

\section{ISBN 978-5-369-02006-7}

Монография подготовлена по материалам XVI Всероссийской конференции и XXVI Всероссийской школы-семинара «Интеграция университетов России в мировое образовательное и научное пространство с учетом региональных особенностей» и посвящена одной из наиболее актуальных тем современной системы образования: международному сотрудничеству российских университетов в императивах регионального развития.

Может быть полезна специалистам управления системы образования России и ее регионов, сотрудникам федеральных и региональных органов власти и управления, а также региональным объединениям академической мобильности. 


\section{ОГЛАВЛЕНИЕ}

ПРЕДИСЛОВИЕ РЕДАКТОРОВ

ГЛАВА 1. МЕЖДУНАРОДНОЕ СОТРУДНИЧЕСТВО

УНИВЕРСИТЕТОВ В ФОРМИРОВАНИИ РЕГИОНАЛЬНЫХ

ИННОВАЦИОННЫХ СИСТЕМ ................................................6

1.1. Особенности и противоречия формирования региональных инновационных систем и ориентиры развития международной активности российских университетов.............................................. 6

1.2. Управление и экспертное сопровождение региональных инновационных инициатив

1.3. Перспективы региональных университетов в контексте глобальных тенденций в сфере высшего образования.

1.4. Международная деятельность университетов в условиях кластеризации региональной экономики.

1.5. Закономерности формирования промышленных кластеров, их внутренних взаимосвязей и сопутствующих функциональных сетей

1.6. Отраслевые компетенции как инструмент развития инновационного потенциала региона 25

1.7. Опыт стран Юго-Восточной Азии

по кластеризации экономики

1.8. Современные IT-технологии для анализа и развития международного сотрудничества регионального университета ......30

\section{ГЛАВА 2. ЭКСПОРТНЫЙ ПОТЕНЦИАЛ УНИВЕРСИТЕТОВ} В РЕГИОНАХ РОССИИ .

2.1. Развитие экспорта образовательных программ российских университетов

2.2. Вклад экспорта образования в экономику региона

2.3. Региональное межведомственное взаимодействие в целях развития экспортного потенциала системы образования.

Опыт участия Новосибирской области в приоритетном проекте «Экспорт российского образования»... 
2.4. Роль опорных университетов в развитии экспортного потенциала систем образования субъектов Российской Федерации. 58

2.5. Качество и динамика международных связей в процессе глобализации системы образования

\section{ГЛАВА З. ЛИНГВОСТРАНОВЕДЧЕСКАЯ ПОДГОТОВКА} ИНОСТРАННЫХ ГРАЖДАН........................................................... 78

3.1. Проектный подход к вопросу о качестве билингвального образования в медицинском вузе: опыт Сибирского государственного медицинского университета

3.2. Проектная деятельность в области обучения трудовых мигрантов и их детей

3.3. Влияние миграционных процессов на деятельность образовательных учреждений российской федерации. .88

3.4. Новые методические приемы и технологии преподавания РКИ в условиях современной образовательной среды .90

3.5. Формирование коммуникативной компетенции учащихся мигрантов и интеграция их в российское общество..........................99

3.6. Адаптация и мотивация учащихся мигрантов ........................... 97

3.7. Особенности работы в многоязыковой и многонациональной среде.

ПРИЛОЖЕНИЯ ............................................................................. 104

Программа XVI ежегодной Всероссийской конференции и XXVI ежегодной Всероссийской школы-семинара 104 Решение XVI Всероссийской конференции и XXVI школысеминара «Интеграция университетов России в мировое образовательное и научное пространство с учетом региональных особенностей» 


\section{ПРЕДИСЛОВИЕ РЕДАКТОРОВ}

Данная монография включает три главы. Они посвящены обсуждению одной из наиболее актуальных тем современной системы образования: международному сотрудничеству российских университетов в императивах регионального развития, реализации инновационной деятельности в интересах модернизации экономики и системы образования для опережающего развития регионов страны.

В первой главе рассмотрены вопросы международной деятельности российских университетов в контексте профессионального сопровождения и поддержки процессов формирования региональной инновационной среды, включая кластеризацию экономики. Рассмотрены особенности и противоречия формирования региональных инновационных систем, а также направления развития международной активности российских университетов в стратегических ориентирах на существенную активизацию процессов регионального развития с учетом управления и экспертного сопровождения региональных инновационных инициатив. Описаны возможности применения современных IT-технологий для анализа и развития международной деятельности российских университетов в современных условиях быстрых перемен, а также перспективы университетов регионов страны в контексте глобальных тенденций в сфере высшего образования.

Вторая глава посвящена анализу отдельных общепостановочных аспектов развития экспорта российского образования, а также вопросам развития региональных инициатив, включая перспективы развития регионального межведомственного взаимодействия, ориентированного на концентрацию ресурсов и возможностей субъектов Федерации в реализации федеральных инициатив по экспорту российского образования.

В третьей главе рассмотрены вопросы формирования лингвострановедческой среды для эффективной подготовки иностранных граждан, успешного позиционирования России в мире посредством обучения русскому языку и через образование на русском языке. Представлен опыт становления билингвальных технологий обучения граждан зарубежных стран. Затронуты вопросы лингвострановедческой подготовки и миграционного учета трудовых мигрантов. 